\title{
UVODNIK
}

\section{NOVA VLOGA OBOROŽENIH SIL KOT ODZIV NA ASIMETRIČNE GROŽNJE}

Asimetrične grožnje smo izbrali za osrednjo temo tokratne številke s poudarkom na novi vlogi oboroženih sil kot enega od več mogočih odzivov države nanje. Asimetrične grožnje niso nekaj novega. V literaturi se asimetrične grožnje omenjajo kot ena najstarejših oblik groženj, čeprav v večini primerov izraz asimetrične ni omenjen. Pojem asimetrija kot izraz za nekaj, kar ni simetrično ali enakovredno, se je pojavil pozneje kot grožnje, ki jih danes poznamo kot asimetrične, in velja za sodobnejšega. V resnici gre pri asimetriji za obliko grožnje, ki je nihče ne pričakuje. Ta se nanaša na organizacijski, kadrovski, količinski in še kateri drugi vidik. Pomembno je, da se asimetrična grožnja pojavi na način, ki nas preseneti. Odzivi nanjo zamujajo, ker take grožnje nismo pričakovali in nanjo (še) nismo ustrezno pripravljeni. Prav zato so asimetrične grožnje velik izziv. Z njimi se lahko spoprijemamo različno, eden izmed načinov je gotovo tudi vojaški. Asimetrično vojskovanje se tako kaže v zelo velikem učinku ob uporabi minimalnega vložka, ob uveljavljanju različnih interesov, najpogosteje posameznika ali skupine proti večji skupini oziroma državi, $\mathrm{z}$ uporabo inovativnih pristopov, $\mathrm{z}$ veliko učinkovitostjo glede na odpor tistega, ki je tarča asimetričnega napada. Pri omenjanju vloge oboroženih sil kot tudi pri njihovem odzivu na asimetrične grožnje se tako vprašanje kot odgovor, ali gre za njihovo novo vlogo, ponujata kar sama. Gre za vrsto groženj, ki imajo bogato zgodovino, a prav zaradi njihove inovativnosti in učinka presenečanja ter škode, ki jo povzročijo, zahtevajo veliko čuječnosti pri vseh, ki jim je zagotavljanje nacionalne varnosti temeljno poslanstvo. V Sloveniji smo se v zadnjih nekaj letih spoprijemali z različnimi grožnjami, ki jih lahko uvrstimo med asimetrične, kot so na primer poplave, žled, množične, skupinske in posamične ilegalne migracije ter covid-19. Nanje se je država odzvala z aktivacijo različnih deležnikov, med drugim tudi vojske. Slovenska vojska se je s številnimi izkušnjami iz preteklosti, ki jih je pridobila doma in v tujini, uspešno vključila v aktivnosti države, da bi normalizirali, pomagali, sanirali in reševali nastali položaj ter zagotavljali red in varnost. Kljub vsemu se vsi deležniki v državi, ki sodelujejo pri vsakokratnem spoprijemanju 
z novimi asimetričnimi grožnjami, vključno s Slovensko vojsko, vedno znova srečujejo z novimi izzivi. Ti se kažejo v različnih pojavnih oblikah kot potrebe po novem znanju, drugačnih oblikah sodelovanja, zagotavljanju specifične logistične podpore, spremembi zakonodaje, posodobitvi samozaščitne opreme za zaposlene in učinkovitosti komunikacijskih ter drugih naprav. Da bi se lahko v prihodnje na asimetrične grožnje bolj pripravili in bili odzivnejši, moramo narediti še veliko za spoprijemanje s prej naštetimi izzivi. To lahko storimo na več načinov. Eden izmed njih je tudi pisanje prispevkov o vlogi oboroženih sil pri asimetričnih grožnjah. Avtorji prispevkov v tej številki z nami delijo različne izkušnje, poglede in zamisli o tem, kako naprej, da bi bili v prihodnje bolje pripravljeni in učinkoviti.

Rok Svetlič se je posvetil vprašanju o pomenu človekovih pravic posameznika, ki kot ilegalni migrant te uveljavlja v državi prihoda, $\mathrm{v}$ odnosu do pravic te države in človekovih pravic njenih državljanov ter vseh tistih, ki v imenu države te pravice uveljavljajo pri svojem delu, medtem ko se spoprijemajo z nezakonitimi migracijami. $\mathrm{V}$ prispevku z naslovom Monistična teorija človekovih pravic in ohromljenost varnostnih sistemov - primer ilegalnih migracij avtor raziskuje vlogo varnostnih sil pri zagotavljanju človekov pravic državljanov.

Skupna interakcija civilnega in vojaškega področja kot orodje pri odzivanju na hibridne grožnje je naslov prispevka avtorjev Thomasa Matyóka in Srečka Zajca, ki menita, da je za odziv na asimetrične, hibridne in druge oblike groženj nujno poiskati nove načine razmišljanja in organiziranja tistih, ki varnost zagotavljajo. Eno njunih glavnih sporočil je, da je za novejše pojavne oblike groženj treba strniti vrste med civilnimi in vojaškimi institucijami.

S spreminjanjem varnostnih groženj se je spremenila tudi narava vojne in vojskovanja, meni Viktor Potočnik, ki v prispevku Sprememba v karakterju bojevanja in transformacija pehotnega oddelka, voda in čete piše o tem, zakaj je do sprememb prišlo, kakšne spremembe so to in kako bi se morale pokazati pri organizaciji, kulturi, doktrini, na usposabljanju in drugih področjih delovanja vojske. Avtor ugotavlja, da novi trendi razvoja na področju vojskovanja prihajajo predvsem iz ameriškega okolja. V prihodnje bo več o tem moralo doreči zavezništvo.

Evropska migrantska kriza leta 2015 je Evropsko unijo soočila z novo preizkušnjo, v katero so bile vključene tudi oborožene sile. Različne države članice so svoje vojske vključile različno. Pet let pozneje pripadnice in pripadniki Slovenske vojske še vedno podpirajo Policijo pri varovanju slovenske meje in reševanju vprašanja vedno večjega števila ilegalnih imigrantov. Več o tem v prispevku Ilegalne migracije in vloga slovenskih oboroženih sil Liliane Brožič.

Pripravljenost evropskih držav na vrnitev tujih borcev Islamske države je naslov članka Denisa Čalete in Sare Perković, v katerem ju zanima, koliko državljani Belgije in Francije, ki so se kot prostovoljci bojevali na strani Islamske države, v 
resnici pomenijo nevarnost za Evropsko unijo in svojo državo, kako se to ugotavlja in kakšni so varnostni ukrepi tako v Evropski uniji kot v obeh državah.

Na vprašanje, kako sistemsko ravnajo ob asimetričnih grožnjah v obliki kibernetskih napadov in nezakonitih migracij v Grčiji, je odgovoril John M. Nomikos. V prispevku Asimetrične grožnje v Grčiji: deskriptivna analiza predstavlja njihovo strategijo kibernetske varnosti in pomen večjega sodelovanja na obveščevalnem področju, da bi preprečili, omejili in zavarovali vse, kar je posebnega pomena za varnost države in družbe, pa tudi ilegalne migrante, ki so žrtve organiziranega kriminala.

Podnebne spremembe tako kot v drugih državah tudi na Madžarskem povzročajo velike preglavice. Kako nanje vplivati, njihov vpliv čim bolj zmanjšati in se z njimi spoprijeti na obrambnem in vojaškem področju, je bil cilj raziskovanja avtorjev Tamása Bereka, Lászla Földija in Józsefa Padányija v prispevku Pravna prizadevanja Madžarske za večjo odpornost na podnebne spremembe.

Kadar govorimo ali beremo o državi, obrambi in vojski, vedno najprej pomislimo na dobro organizacijo, dinamično delo, red, disciplino in varnost. Varnost za vse. Naj tako ostane. 